\title{
Making Çents
}

\section{Out of Solar}

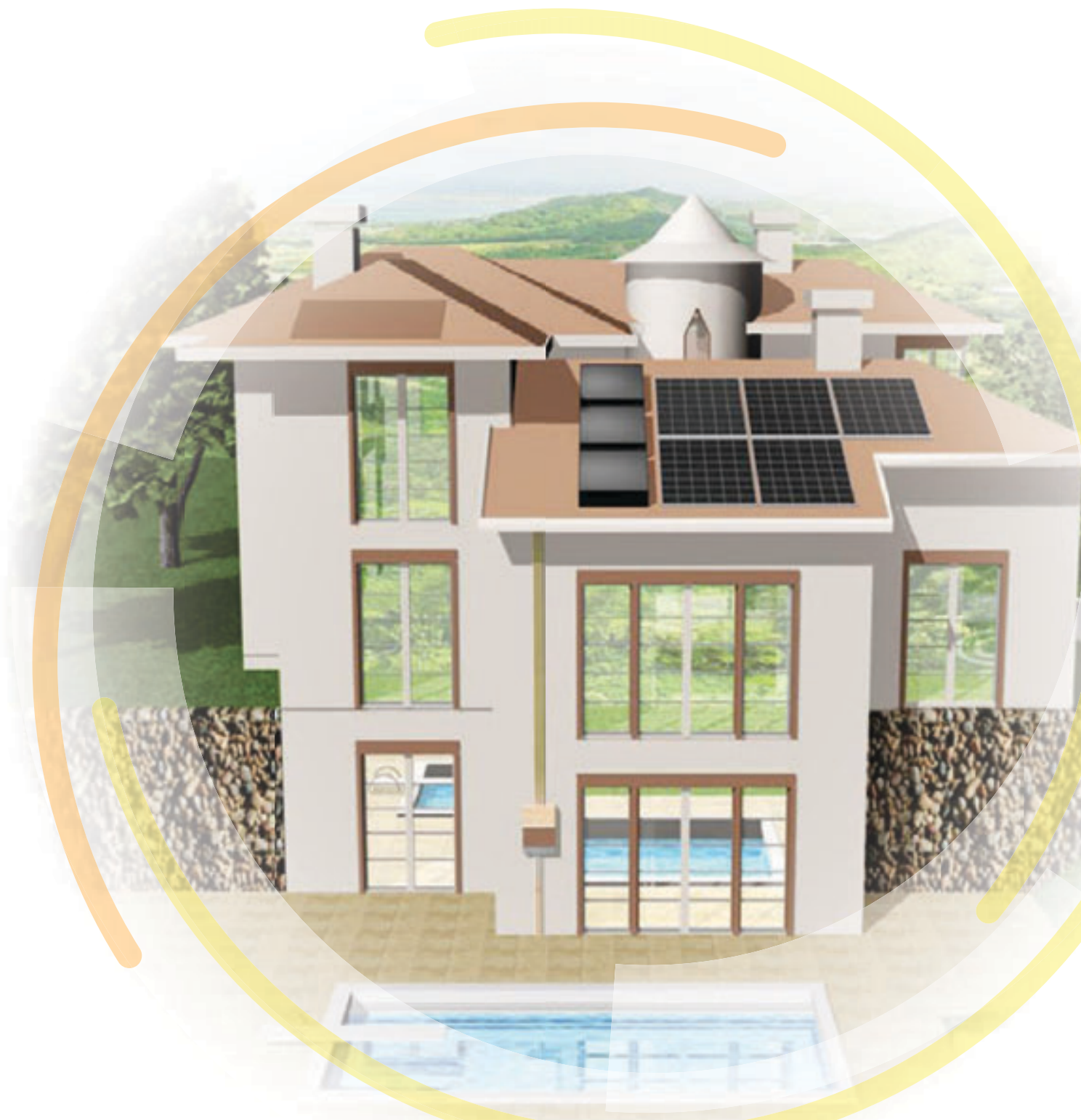

Put More Power Into 
today's residential and commercial buildings, the most commonly used solar energy

technologies are solar electric (also known as photovoltaic or "PV") and solar hot water heating systems. PV systems convert sunlight directly into electricity, and solar water heating systems collect the sun's heat for use in water and space heating. Every year, more builders are reaping the benefits of giving their buyers the solar option.

Why should builders sell solar in their homes? - Differentiates you from other builders

- Sells faster than homes without green options ${ }^{*}$

- Saves money with shorter sales cycles and less inventory*

- Complements good design and quality constructio

- Enhances corporate image as environmentally responsible builder

*Clarum Homes absorption rate, or the pace homes are sold, is about twice the state average in California.

\section{Your Solar Team}

Because the benefits of incorporating solar vary from community to community, these are the key players every builder should use as resources.

- Solar installer/contractor - to help determin permits, training, and utility interconnection

- DSIRE Web site - to find the list of financial incentives offered in your state

- Utility - to identify specific requirements for connecting to the grid (interconnection and net metering) and incentives

- City officials - to find local code requirements for solar

- Architect - to identify ways to incorporate solar into building plans

- Manufacturer - to find specific costs, including bulk discounts

- State Solar Organization - to find available resources, training, and certification

- Tax professional - to apply for financial incentives

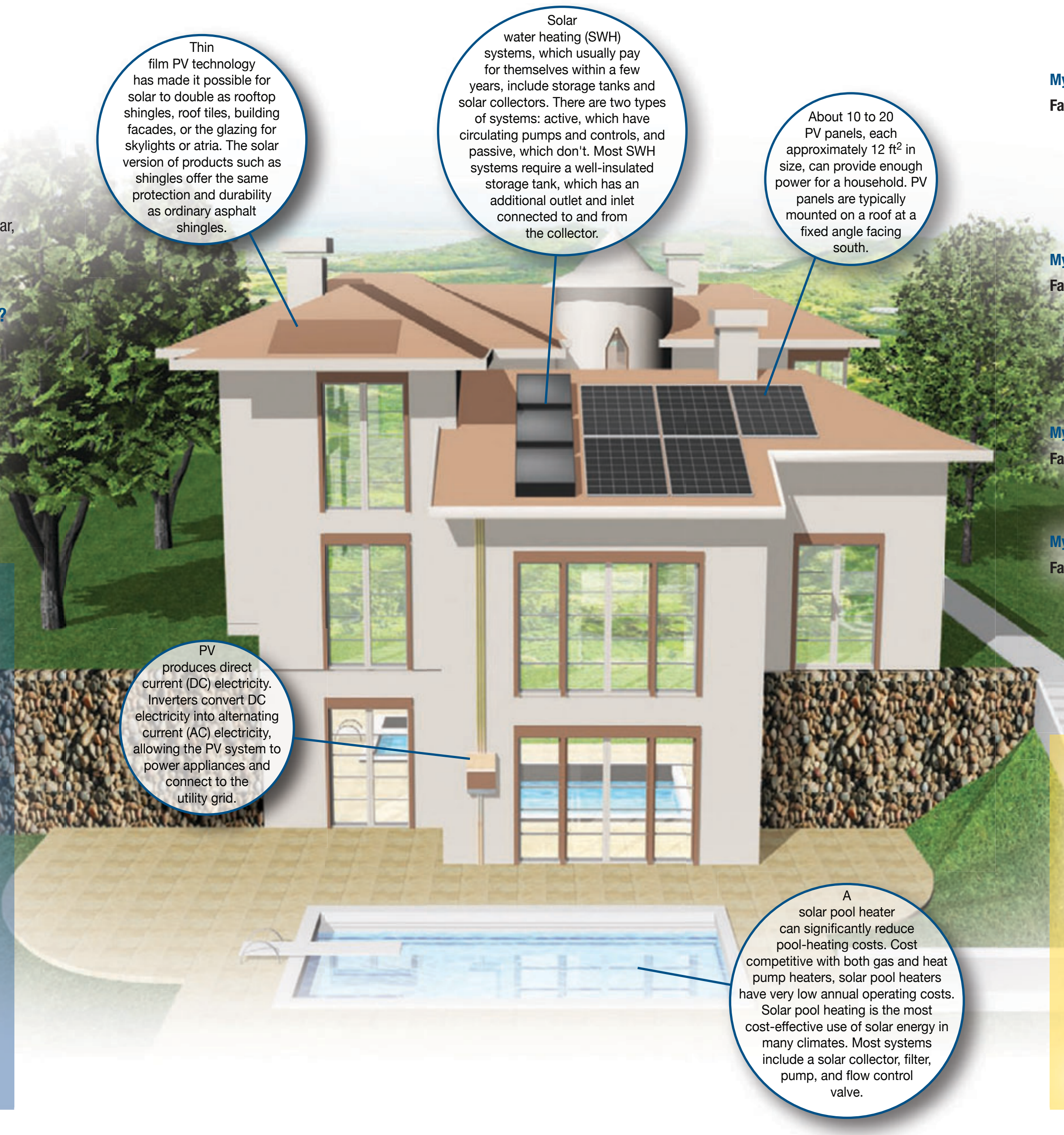

Myth: Solar energy systems are unreliable.

Fact: Solar electric systems have been tested to rigorous standards by public and private organizations. Solar panels suffer very little degradation over time and are generally rated to last up to 25 to 30 years. A solar energy system will have nearly the same output in year 25 as it did on day 1.

yth: Solar energy systems are unattractive. fact: New advances in solar technology and roofmounted systems have created more stylish systems that blend into their surroundings. Some systems are nearly building materials such ar roftional and window awnings as roof shingles

th. Solar energy systems are difficult to maintain. Fact: Solar panels require very little maintenance, and because of their slick surface and the slope at which they are typically mounted, they require virtually no cleaning.

Myth: Solar is too expensive.

Fact: Solar energy systems have decreased greatly in price over the past 15 years. With generous state rebates and federal tax write offis, the actual cost a builder faces can be as low as $40 \%-50 \%$ of the solar system's retail price. Homeowners will also see an increase in home values and a positue annual net cash flow from a higher mortgage payment offset by lower utility bills.

\section{Solar America Initiative}

SAl was launched in 2006 by the U.S. Department of Energy to accelerate the development of advanced competitive.

To address marketplace barriers, SAl activities include:

Providing technical and regulatory solutions for states and utilities

- Partnering with cities ready to build sustainable solar infrastructures

- Partnering with industry to address codes, standards, and interconnectivity issues. Visit www.eere.energy.gov/solar/solar_america/ index.html for more information. 


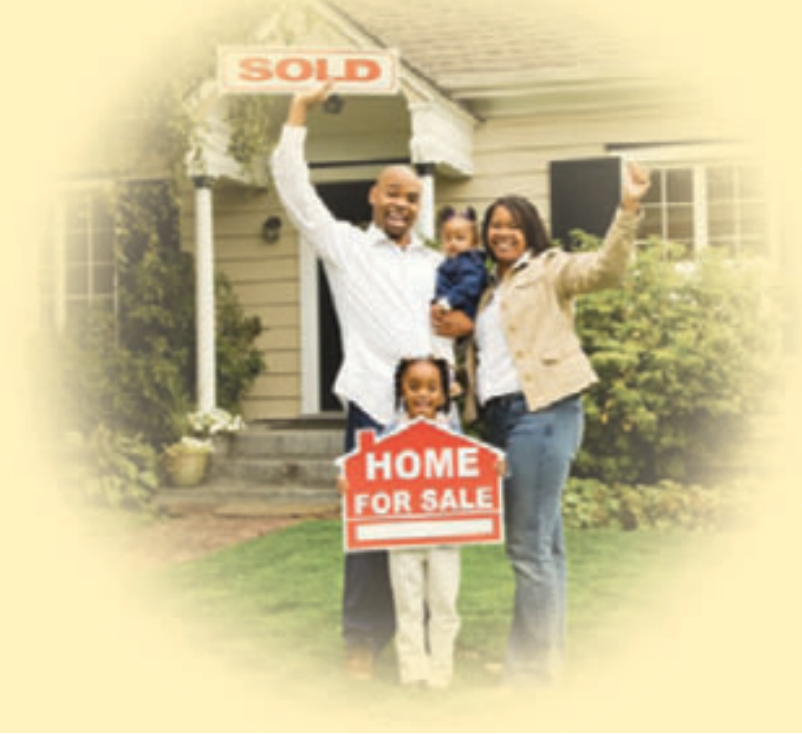

"We set out to provide exceptional value for our customers by adding solar power, and in the process we did something exceptional for our business."

\section{- John Suppes, President of Clarum Homes of Palo Alto, California}

"We sold 23 of our first 30 homes in the first three months, even though the market in Sacramento is very slow right now; it is the slowest housing market in the country."

—Mark Fischer, Senior Vice President of Grupe, a California-based builder producing 200-300 homes per year

\section{Selling Tips}

Solar can be good for your business by differentiating your homes from others on the market. It can also enhance your reputation as an innovative, environmentally responsible builder in your community. Because it will be important for your staff to understand the benefits of solar, below are some sales tips from builders who've had success promoting the advantages of solar.

- Educate customers and sales professionals about the positive annual net cash flow from a higher mortgage payment offset by lower utility bills.

- Make buyers aware of energy-efficient mortgages.

- Take out the guesswork. Integrate the solar system into the entire home purchase rather than offering it as an option.

- Place displays and samples in model homes or showrooms.

- Offer training sessions and open houses to draw in and educate consumers.

- Collect testimonials to educate customers and build confidence.

- Produce brochures, videos, and signs that demonstrate how buyers will save money and help the environment.

- Provide reprints of magazine articles. Vendors and trade associations have excellent materials.

- Add simple educational information to your Web site.

- Distribute a news release about solar homes to the local media to draw traffic.
For more information on installing solar technologies, download the complete Building America High-Performance Home Technologies: Solar Thermal \& Photovoltaic Systems publication at www.eere. energy.gov/buildings/building_america/pdfs/41085.pdf.

Additional Resources

Educational and Technical Assistance

U.S. Department of Energy Solar Program

http://solar.energy.gov

National Renewable Energy Laboratory
www.nrel.gov

DOE Building America Program

www.buildingamerica.gov

American Solar Energy Society
www.ases.org

Interstate Renewable Energy Council
www.irecusa.org

Solar Energy Industry Association

www.seia.org

Solar Electric Power Association

www.solarelectricpower.org

Economic Information and Tools

State Incentives

www.dsireusa.org

Solar Contractors and Cost Estimator
Operated for the

U.S. Department of Energy, Office of

Energy Efficiency and Renewable Energy by Midwest Research Insititute • Battelle

Printed with a renewable-source ink on paper containing at Pent $50 \%$ wastepaper, including $10 \%$ postconsumer waste
DOE/G0-102008-2553 January 2008

A Strong Energy Portfolio for a Strong America. Energy efficiency and clean, renewable energy will mean a stronger economy, a cleaner environment, and greater energy independence for America. Working with a wide array of state, community, industry, and university partners, the U.S. Department of Energy's Office of Energy Efficiency and Renewable Energy invests in a diverse portfolio of energy technologies. 